\title{
Anthropogenic Aerosol Influences on Mixed-Phase Clouds
}

\author{
Ulrike Lohmann $^{1}$ (D)
}

Published online: 6 February 2017

(C) The Author(s) 2017. This article is published with open access at Springerlink.com

\begin{abstract}
Aerosol effects on mixed-phase clouds (MPCs) are more complex than in warm clouds because aerosol particles can act both as cloud condensation nuclei and as ice nucleating particles and more microphysical pathways exist. Stratiform MPCs are most prevalent in the Arctic where cloud top cooling enables heterogeneous ice formation and in orographic terrain where large updrafts prevail. Recently, aerosol effects on stratiform MPCs have also been considered in global climate models. The estimated effective aerosol radiative forcing due to aerosol-cloud and aerosol-radiation interactions (ERFaci+ari) at the top-ofthe-atmosphere (TOA) in stratiform warm and MPCs, which is an update of the estimate given in the fifth assessment report (AR5) of the Intergovernmental Panel of Climate Change, is $-1.2 \mathrm{~W} \mathrm{~m}^{-2}$ with a $5-95 \%$ range between -0.8 and $-2.0 \mathrm{~W} \mathrm{~m}^{-2}$. Since AR5, only one new estimate of ERFaci+ari including aerosol effects on both stratiform and convective clouds of $-1.4 \mathrm{~W} \mathrm{~m}^{-2}$ has been published. In all cases, ERFaci+ari is dominated by changes in the shortwave TOA radiation with changes in the longwave TOA radiation amounting to $0.15 \mathrm{~W} \mathrm{~m}^{-2}$.
\end{abstract}

Keywords Anthropogenic aerosols · Aerosol radiative forcing · Mixed-phase clouds · Global climate models

This article is part of the Topical Collection on Aerosols and Climate

Ulrike Lohmann

ulrike.lohmann@env.ethz.ch

1 ETH Zurich, Institute for Atmospheric and Climate Science, Universitaetsstrasse 16, 8092 Zurich, Switzerland

\section{Introduction}

Emissions of anthropogenic aerosols and their precursor gases have substantially increased since pre-industrial times. Some anthropogenic aerosols, such as sulfates, nitrates, and some organic aerosols, are hygroscopic or hydrophilic. They are good cloud condensation nuclei $(\mathrm{CCN})$ and with that influence the microphysical properties of warm clouds, denoting clouds consisting purely of liquid water. An increase in CCN leads to more cloud droplets. If the same amount of water vapor condenses on more cloud droplets, the cloud droplets cannot grow as large and will be smaller. The total cross-sectional area of the polluted (anthropogenically influenced) cloud thus is higher and reflects more solar radiation back to space. This effect is known as the Twomey effect [96] or radiative forcing due to aerosol-cloud interactions (RFaci, [9]).

In addition, rapid adjustments occur that further modify the radiative budget at TOA through changes within the atmosphere or at the surface. These adjustments operate on timescales that are much shorter than the timescale of global warming and are distinguished from feedbacks which operate through changes in climate variables as a response to a change in surface temperature. In a cloud that consists of smaller cloud droplets, the droplets are less likely to collide and coalesce, which retards precipitation formation [1]. If such a delay increases the cloud's lifetime or causes faster evaporation of the small droplets is still unclear [37]. Other fast adjustments include changes in the phase of the cloud or changes in its coverage. These adjustments are included in the effective radiative forcing due to aerosol-cloud interactions (ERFaci, being the sum of RFaci and fast adjustments). The majority of the estimates of ERFaci from global climate models (GCMs) is more negative than RFaci alone 
[55]. In the global annual mean ERFaci+ari that includes also the radiative forcing due to aerosol-radiation interactions (ari) was estimated to be $-0.9 \mathrm{~W} \mathrm{~m}^{-2}$ in IPCC AR5 [9] with an uncertainty range of -0.1 to $1.9 \mathrm{~W} \mathrm{~m}^{-2}$. Since then, a number of new estimates has been published using state-of-the-art GCMs, all of which arrive at a more negative ERFaci+ari [13, 23, 24, 31, 44, 61, 83, 86, 104]. Even the study that is based on satellite observations reports an ERFaci+ari of $-0.95 \mathrm{~W} \mathrm{~m}^{-2}$ [12], which is at the upper end of the satellite-based estimates in IPCC AR5 [9].

Stratiform mixed-phase clouds (MPCs) or layers of mixed-phase in nimbostratus clouds can be found at temperatures between 0 and $-38{ }^{\circ} \mathrm{C}$ and contain both supercooled liquid water and ice. More precisely, Korolev et al. (2003) defined MPCs as clouds in which the ratio of the ice water content to the sum of the liquid water and ice water content was measured to be between 0.1 and 0.9 [48]. Convective clouds with a large vertical extent and cold cloud top temperatures can also have a mixed-phase region. These clouds and possible aerosol effects on them are discussed in the "Aerosol Effects on Deep Convective Clouds" section. The majority of precipitation in mid-latitudes originates in clouds containing ice [68] but melts to raindrops or drizzle drops on the way to the ground. While precipitation from pure ice clouds (e.g., high cirrus clouds) rarely reaches the ground, the precipitation-forming clouds are mainly MPCs (stratiform and convective) in which ice crystals quickly grow to precipitation-sized particles and leave the cloud. Because of the larger sizes of ice crystals and their smaller index of refraction as compared to cloud droplets, even for the same water content ice clouds are optically thinner than liquid water clouds. Taking into account that precipitation reduces the water content of glaciated clouds, they are optically much thinner and reflect much less shortwave radiation back to space than liquid water clouds. This effect is partly compensated by a reduced emission in the longwave. In short, knowledge about the size distribution of cloud droplets and ice crystals in MPCs is important both for the hydrological cycle and the radiation budget.

In this article, I will first discuss the microphysical processes in MPCs ("Aerosol Effects on Stratiform and Shallow Convective MPCs"), then discuss anthropogenic aerosol effects on stratiform MPCs ("Aerosol Effects on Stratiform and Shallow Convective MPCs"), orographic MPCs ("Aerosol Effects on Orographic MPCs"), and on deep convective clouds ("Aerosol Effects on Deep Convective Clouds") before discussing global estimates of ERFaci+ari in the "Aerosol Radiative Forcing Due to Aerosol-Cloud and Aerosol-Radiation Interactions" section and finishing with conclusions.

\section{Microphysical Processes and Aerosol Effects in MPCs}

MPCs are thermodynamically unstable because the saturation vapor pressure over ice is smaller than over supercooled liquid water. If the environmental vapor pressure lies between the saturation vapor pressure of supercooled water and ice, then the ice crystals grow at the expense of the evaporating water droplets. This process is called the Wegener-Bergeron-Findeisen (WBF) process [4, 21, 100]. The result of this process can be observed in so-called hole punch clouds [30, 71] (Fig. 1), where in the wake of an aircraft penetrating the supercooled liquid cloud, locally the temperature decreases sufficiently for ice formation. Due to the WBF process, ice crystals have grown large enough to sediment out of the cloud.

The effect of anthropogenic aerosols on MPCs is much more uncertain than on warm clouds because more microphysical processes exist and also changes in the liquid phase can influence MPCs. For instance, a delay of the warm rain process due to more and smaller cloud droplets as discussed above keeps more condensate in the cloud so that more latent heat can be released upon freezing. This effect

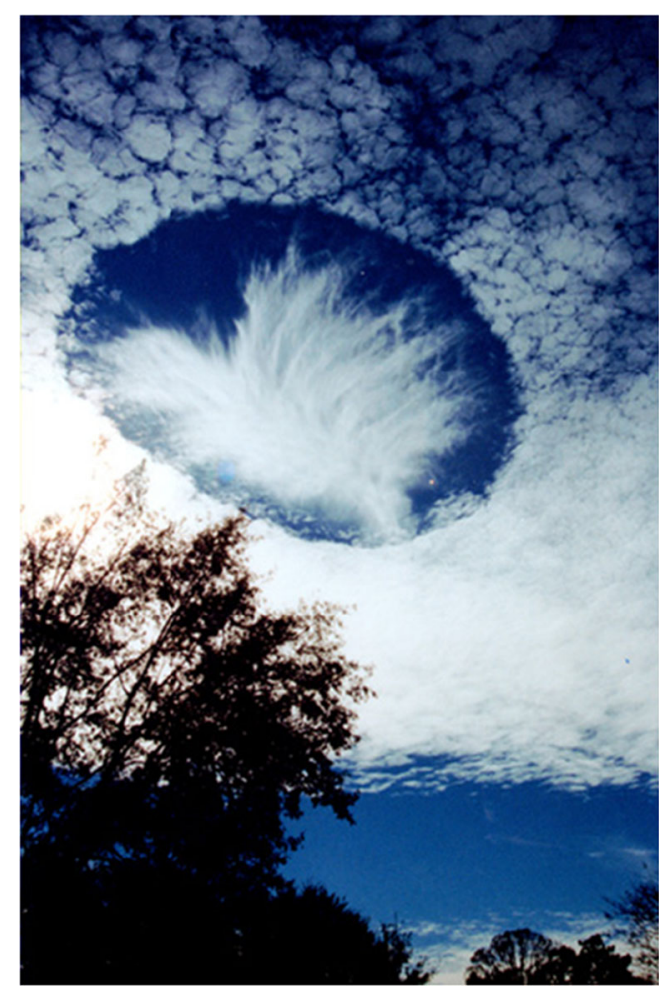

Fig. 1 Hole punch cloud. Photograph taken and reproduced with permission of Joel Knain (http://apod.nasa.gov/apod/ap040112.html). For more explanations about hole punch clouds please refer to Heymsfield et al., 2010 [29] and 2011 [30] 
is partly compensated by the additional weight of the condensed water that reduces the buoyancy inside the cloud. The net increase in buoyancy in polluted as compared to clean clouds has been made responsible for the invigoration of deep convective clouds [81] and been referred to as the thermodynamic indirect effect [15]—see the "Aerosol Effects on Deep Convective Clouds" section.

In addition to changes in the number concentration and size of cloud droplets, changes in MPCs can be triggered by a change in the number concentration of anthropogenic aerosols can act as ice nucleating particles (INP). INP differ from $\mathrm{CCN}$ in that they need to have active sites that can stabilize ice germ formation. The identity of what constitutes an active site is still unknown and area of active research [40]. Many previous studies have suggested that INP need to be solid or crystalline and typically have diameters larger than $0.1 \mu \mathrm{m}[62,75]$, examples of which are mineral dusts [34, 72], biological particles such as bacteria, fungal spores, and pollen [16], but can also be biogenic particles from the ocean surface, oxidized biogenic forest emissions, or macromolecules from plant and ocean matter [76, 77, 102].

So far, it is neither known if carbonaceous aerosols are good INP nor if anthropogenic activity has increased the INP concentration. If soot aerosols, agricultural dusts, industrial metal particles, ashes, and/or biomass burning particles were good INP, then INP would have increased through anthropogenic activity causing an increase in the ice crystal number concentration (ICNC) assuming the macroscopic conditions causing cloud formation remain unchanged. Due to the WBF process, an increase in ICNC leads to a faster glaciation of supercooled liquid clouds and MPCs, an increase in precipitation, a decrease in cloud cover, and a reduction in reflected shortwave (SW) radiation [51]. This so-called glaciation effect buffers some of the initial perturbations in warm clouds through a decrease in the coverage and water content of the overlying clouds in the mixed-phase temperature range between 0 and $-38^{\circ} \mathrm{C}$. In addition, ice crystals and snow flakes from these clouds accrete with cloud hydrometeors (cloud droplets and ice crystals) in lower-lying clouds and reduce also their water content. Suggestions for such a buffering were found in preliminary studies with the Norwegian Earth System Model (NorESM) [44] and can be explained theoretically [26].

If, however, the main effect of anthropogenic activity were a coating of INPs with acids (sulfuric acid, nitric acid), this would reduce their ice nucleating ability and result in fewer ice crystals that grow to larger sizes and sediment more readily without converting the whole MPC into an ice cloud [25]. Alternatively, ice may only form at colder temperatures. In any case, this so-called deactivation effect causes an increase in the amount of supercooled liquid water and operates in the same direction as ERFaci for warm clouds. The deactivation effect seems to dominate over the glaciation indirect effect in some GCMs [33, 91].

\section{Aerosol Effects on Stratiform and Shallow Convective MPCs}

Stratiform MPCs are prevalent in the Arctic [67, 89] and in orographic terrain $[28,50,57]$. In situ observations and surface remote sensing suggest that clouds in the mixedphase temperature range in mid-latitudes tend to consist almost entirely of ice or of liquid water [10, 11, 48]. This agrees with satellite observations over the Southern Ocean and North Pacific, which have shown that the most common cloud types are clouds with supercooled droplets at their tops $[6,65]$. Glaciated cloud tops at temperatures warmer than $-20^{\circ} \mathrm{C}$ are rare. A large portion of cloud tops remains ambiguous from the MODIS satellite, which means they could be MPCs or have signals from multiple cloud layers [65]. On a global scale, the fraction of supercooled water in MPCs at various temperatures from the ECHAM6 and different versions of the CAM GCM has been compared to CALIOP satellite estimates. None of the models captured the observed variation in the supercooled fraction with temperature correctly but either simulated too small or too high values at all temperatures [46]. This is partly related to differences in INP concentrations and partly to differences in the involved parameterized microphysical processes.

Increasing the supercooled liquid water in shallow convective clouds substantially reduced the bias in the absorbed shortwave radiation in the present-day climate over the Southern Ocean in the CAM5 GCM [42]. An error in the fraction of supercooled liquid water in stratiform MPCs in the present-day climate also has consequences for projections of global mean temperature at the time of $\mathrm{CO}_{2}$ doubling [94]. If ice in MPCs is overestimated in the present-day climate, a larger portion of that will be found in the liquid phase in a warmer climate. This overestimates the negative cloud phase feedback that partly offsets global warming. If the bias of the amount of ice in MPCs is reduced, the cloud phase feedback will be smaller and the temperature at the time of $\mathrm{CO}_{2}$ doubling will be higher [94].

On a regional scale, low-level MPCs were studied extensively in the Arctic, where they occur frequently and are persistent $[67,78,89,103]$. MPCs may be stabilized due to anthropogenic activity due to the deactivation effect [25] such that the sulfate-induced inhibition of freezing leads to 
fewer and larger ice crystals both in MPCs and pure ice clouds [27]. Aerosol effects on Arctic MPCs have received lots of attention because MPCs play a central role in Arctic climate change and sea ice loss [41]. The effect of anthropogenic aerosols on Arctic MPCs is not limited to the reflection of shortwave radiation, but also affects the longwave radiation by increasing the longwave emissivity $[2,22,59]$.

Evidence of RFaci is sometimes visible in terms of shiptracks [17] even though the global coverage of shiptracks of $0.002 \%$ [87] is very small due to the special environment that they need to form in. Also, not all shiptracks show an increase in albedo, because of fast adjustments. The effective radius decreases by about $20 \%$ in warm cloud and MPC shiptracks, because the water vapor is distributed over more cloud particles, which limits their growth (Fig. 2). Due to buffering in MPCs, the increase in albedo seems to be smaller than in shiptracks in warm clouds. Of the nearly 300 shiptracks evaluated by Christensen et al. [14], the albedo increase amounts to less than $2 \%$ in shiptracks in MPCs as compared to the $8 \%$ increase in warm clouds (Fig. 2). The smaller albedo increase is caused by the significantly larger precipitation formation rate in the ice phase via the glaciation indirect effect that leads to a decrease of the total water path of $16 \%$ as compared to suppression of precipitation in the warm phase and almost no change in the total water path (Fig. 2).

Also cloud-resolving model simulations of Arctic clouds showed smaller albedo increases in MPCs than in warm clouds [49]. Observations during the Indirect and SemiDirect Aerosol Campaign (ISDAC) campaign in April 2008 were used to test various aerosol indirect effects in MPCs by correlating different cloud properties to the total accumulation mode aerosol concentration above and below cloud [35]. There were indications that in some instances, mixing of aerosol particles into the cloud from above caused a glaciation indirect effect. Other cases suggested that secondary ice crystal production becomes less efficient because the number of cloud droplets large enough to cause splintering decreases with increasing aerosol load. The riming indirect effect (see below) did not seem to play a major role [35].

Little research has so far been conducted on possible aerosol effects on MPCs in the storm tracks of both hemispheres. Of the few studies that exist in the North Pacific, where these effects should be strongest due to the high anthropogenic emissions in East Asia, the results remain inconclusive as to whether or not anthropogenic aerosols noticeably increase precipitation from extratropical cyclones $[39,99,105]$.

\section{Aerosol Effects on Orographic MPCs}

Orographic clouds and precipitation can be particularly prone to strong aerosol-cloud-precipitation interactions [38, $70,80,106]$ because the time for precipitation development is limited to the ascending branch of mountain flow. At the same time, the time for precipitation formation is constrained by the strong dynamical forcing of the orography.

Observations taken on top of Jungfraujoch in the Swiss Alps show persistent MPCs in those cases in which the updraft velocities are high enough to exceed saturation with respect to liquid water. This allows simultaneous growth of supercooled liquid droplets and ice crystals [57]. However, as the ICNC exceeds the concentration of INP by orders of magnitude, no influence of anthropogenic aerosols on the persistence of MPCs could be deduced.

Decreasing snowfall rates with increasing anthropogenic aerosol loads have been observed in the Rocky Mountains through correlations of the snowfall rate with sulfate concentrations [8] and by comparing two case studies with a similar liquid water content [7]. The authors suggested that this anticorrelation is caused by a reduction in the collision efficiency of snowflakes with smaller cloud droplets, which reduced the riming rate, and referred to it as a
Fig. 2 Bar chart of cloud property changes due to ship pollution for warm $\left(T>0{ }^{\circ} \mathrm{C}\right)$ and cold $\left(T<-5{ }^{\circ} \mathrm{C}\right)$ cloud tops. Figure adapted from Christensen et al. (2014) [14]. Statistics are based on the fractional change (in \%) between the polluted and unpolluted clouds using 297 ship tracks. Solid error bars denote the 5-95\% confidence interval. The dashed bar is truncated to fit inside the figure

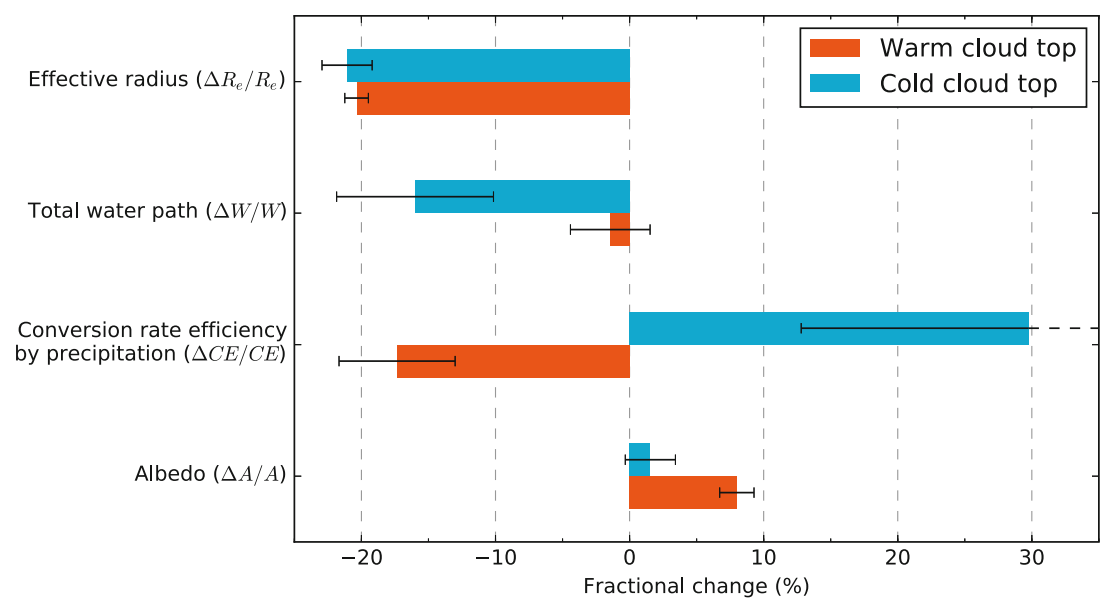


riming indirect effect. As riming leads to efficient precipitation formation in MPCs, a retardation of riming prolongs the development of precipitation and can cause some precipitation to spill over to the leeward side of the mountain $[84,106]$. In a comparison of different numerical models, neither a decrease in riming was a robust result nor did an increase in aerosols necessarily lead to a reduction in precipitation [69]. Given the large scatter in the data [8], the model findings do not necessarily contradict the measurements. This is because the effect of anthropogenic aerosols on cloud microphysics and orographic precipitation not only depends on the temperature of the MPCs and the concentrations of CCN and INP, but also on the synoptic situation and cloud dynamics and how these processes are described and interact with each other in numerical models $[18,20$, $60,69,70]$.

In GCM simulations, the riming indirect effect was found to be of minor importance [52]. Instead, the increased cloud optical depth due to pollution aerosols reduced the solar radiation and hence the temperature at the Earth surface and within the atmosphere. This in turn led to more ice in the atmosphere and hence more snowfall.

\section{Aerosol Effects on Deep Convective Clouds}

In addition to the aerosol effects on stratiform MPCs introduced above, a thermodynamic effect has been suggested $[15,79,81]$. Whereas in pristine deep convective clouds, cloud droplets collide and coalesce into sedimenting raindrops, in a polluted cloud precipitation formation via collision-coalescence is suppressed (Fig. 3). Instead, cloud droplets are advected into higher levels with colder temperatures. Once they reach temperatures below $0{ }^{\circ} \mathrm{C}$, they can freeze. The freezing temperature depends on the size of the cloud droplets, such that smaller droplets homogeneously freeze at colder temperatures than larger drops [75] because the chance of forming a critical ice embryo increases with increasing droplet size. This is relevant if heterogeneous nucleation and the WBF process are not fast enough to cause glaciation of the cloud in the mixed-phase region. This can be the case in continental deep convective clouds where supercooled droplets were found down to $-37.5^{\circ} \mathrm{C}$ [82]. Also, heterogeneous freezing depends on the droplet size because larger droplets have a higher chance to contain more or better INPs.

Freezing releases latent heat aloft and invigorates these cloud systems [47], but also in the lower levels of the cloud more latent heat is released by enhanced condensational growth $[88,93]$. This is partly counteracted by the reduced buoyancy due to increased water loading. Ice crystals forming in upper levels grow into precipitation-sized particles that fall against the updraft. At temperatures above $0{ }^{\circ} \mathrm{C}$, they melt and consume latent heat. For the same amount of surface precipitation, the polluted cloud has a larger upward heat transport because more precipitation originates via the ice phase. The larger heat transport results in an invigoration of the convective clouds with overall more precipitation, despite the slower conversion of cloud droplets to raindrops. The more numerous but smaller ice crystals in polluted clouds that sediment slower were found to increase the cloud cover of the stratiform anvil in the mature and dissipating stages of deep convective clouds [19]. This may lead to an increased reflection of shortwave radiation as shown in Fig. 3.

Model simulations using a cloud system-resolving model show that either a weakened or an enhanced response of the surface precipitation rate of an idealized supercell storm to polluted conditions (realized by increasing the cloud droplet number concentration from 50 to $750 \mathrm{~cm}^{-3}$ ) can be found [66]. If the polluted supercell storm produces more or less surface precipitation depends on how the cold pool strength changes in response to pollution, which in turn depends on how the cloud microphysical and thermodynamic processes are modified in different simulation set-ups. The cold pool strength is larger in those simulations that produce a larger convective mass flux and more surface precipitation. Differences in the response of deep convection to aerosol perturbations simulated by increasing the cloud droplet number concentration from 100 to $2500 \mathrm{~cm}^{-3}$ using two different state-of-the art cloud microphysical schemes within the WRF high-resolution model point to the importance of the treatment of snow and graupel (being one-moment in one scheme and two-moment in the other). The opposite responses in liquid water and ice mass of the polluted deep convective cloud compared to the clean cloud using these schemes show deficiencies in our understanding of convective processes and our ability to parameterize them well [101].

\section{Aerosol Radiative Forcing Due to Aerosol-Cloud and Aerosol-Radiation Interactions}

In IPCC AR5, GCM estimates of ERFaci+ari have been stratified into those that only include aerosol effects on warm stratiform clouds and those that went beyond that. In the category that included also aerosol effects on MPCs, the estimates ranged between -0.3 and $-2 \mathrm{~W} \mathrm{~m}^{-2}$ [9]. Part of this range can be explained by differences in the importance of the glaciation vs. the deactivation effect (see section Microphysical Processes and Aerosol Effects in MPCs) in different GCM simulations. Six studies considering aerosol effects on MPCs have been published since IPCC AR5, with best estimates of ERFaci+ari between -0.9 and $-2.5 \mathrm{~W} \mathrm{~m}^{-2}$, i.e., covering a similar range but with more negative values than prior to AR5. Thus, the overall range of ERFaci+ari has increased. 


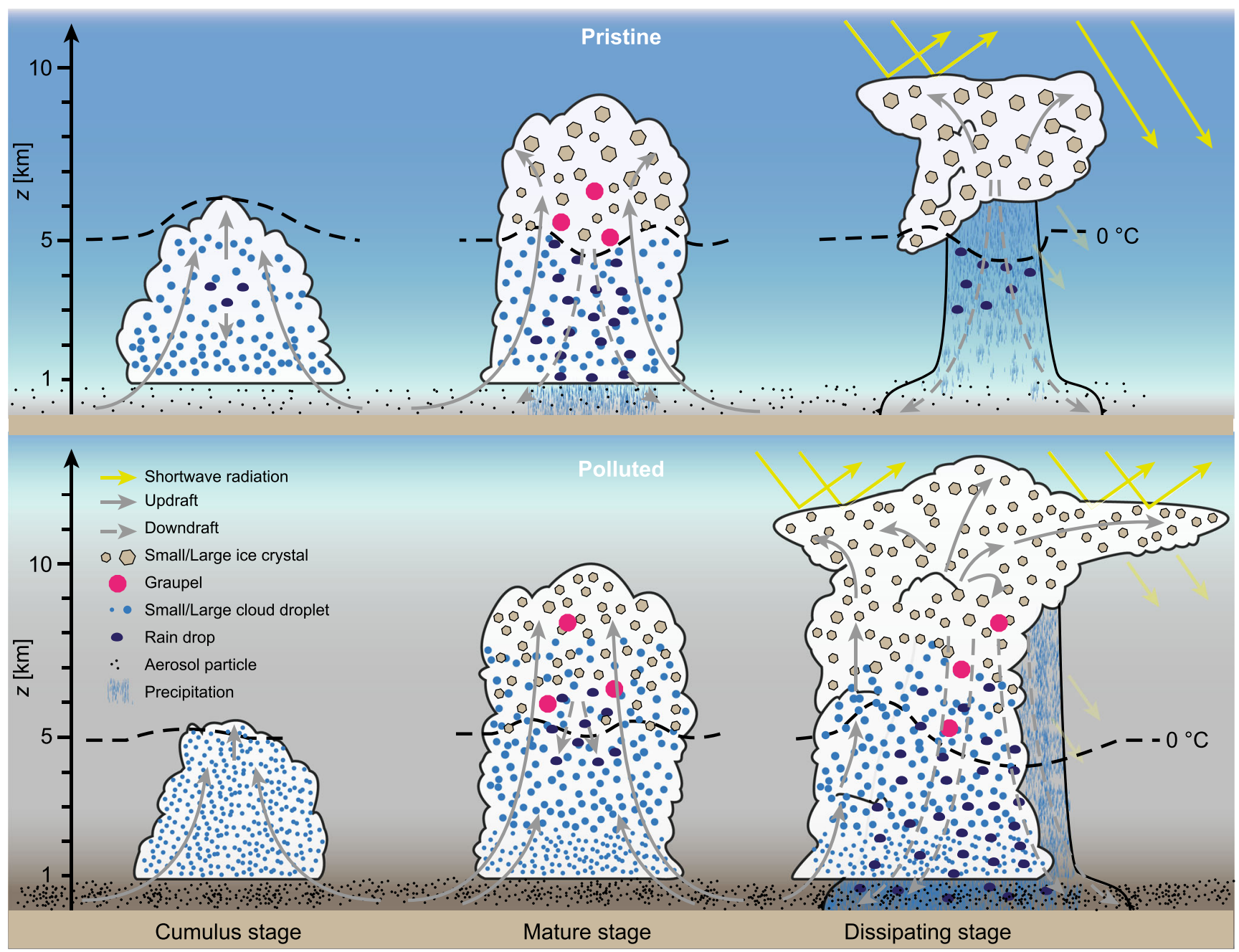

Fig. 3 Evolution of deep convective clouds developing in the pristine (top) and polluted (bottom) atmosphere. Figure courtesy of Fabian Mahrt modified from Rosenfeld et al. (2008) [81]

A study conducted with CAM3 + coupled to the IMPACT aerosol module obtained an even more negative ERFaci+ari of $-2.8 \mathrm{~W} \mathrm{~m}^{-2}$ (compared to $-2.5 \mathrm{~W} \mathrm{~m}^{-2}$ ) in case that marine organics do not serve as INP [104]. Such a reduction of ERFaci+ari caused by additional INP is consistent with the glaciation indirect effect discussed above.

In sensitivity simulations with CAM5 where different aspects of aerosol-cloud interactions were changed, a much larger global influence of the WBF process on MPCs was found than to differences in the ice nucleation scheme [23] (see Fig. 4 entries "Ice Nucleation" vs. "WBF process"). In order to correctly simulate precipitation processes, it is important to place more emphasis on growth by accretion than by autoconversion as achieved most physically by treating precipitation prognostically [24]. This favors growth by accretion, which is independent of the cloud droplet number concentration, and hence reduces ERFaci+ari. The influence of prognostic precipitation on ERFaci+ari is, however, smaller than using different autoconversion rates (Fig. 4 compare entries "Prog Precip" vs. "Autoconv"), a different activation scheme (Fig. 4 entry "Activation") or by changing the WBF process. The largest sensitivity was obtained when CAM5.3 was coupled to the turbulent and shallow convection scheme CLUBB that considers aerosol effects on shallow convective clouds (Fig. 4 entry "CLUBB"). ERFaci+ari from the CAM5.3 sensitivity experiments ranged between -0.7 and $-1.6 \mathrm{~W} \mathrm{~m}^{-2}$.

In simulations with the ECHAM6 GCM coupled to the HAM2 aerosol scheme that include aerosol effects on stratiform warm and MPCs, the sensitivity of ERFaci+ari to aerosol processing, i.e., how important it is to account for the number of aerosol particles that are incorporated into cloud droplets and ice crystals during activation, nucleation, scavenging, and collisions, was investigated [73]. Aerosol processing reduced ERFaci+ari by 0.1 to $0.4 \mathrm{~W} \mathrm{~m}^{-2}$ to -1.1 respectively $-0.9 \mathrm{~W} \mathrm{~m}^{-2}$ depending on the stability function used in the turbulence scheme. Using ECHAM5-HAM2, it was shown that treating subgrid 
Fig. 4 Percentage change of ERFaci+ari in response to various aspects that influence aerosol-cloud interactions. Figure modified from Gettelman (2015) [23]

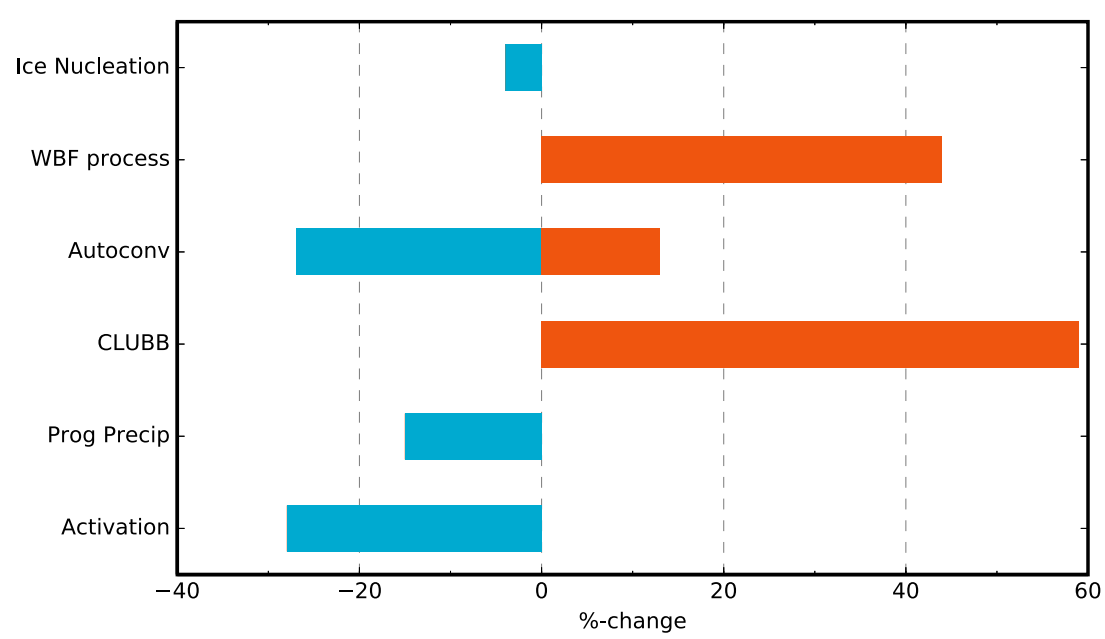

scale variability by introducing stochastic subcolumns in the calculations of cloud droplet activation and autoconversion (collision-coalescence of cloud droplets to form raindrops) reduced ERFaci+ari by $0.3 \mathrm{~W} \mathrm{~m}^{-2}$ to $-1.3 \mathrm{~W} \mathrm{~m}^{-2}$ [95].

Because of the long timesteps in GCMs, most microphysics scheme only treat cloud water and ice as prognostic variables and diagnose the amount of precipitation every timestep. Recently, some climate modeling groups started to treat precipitation prognostically [24, 74, 86]. Because fast falling raindrops can violate the Courant-FriedrichsLewy criteria, GCMs with prognostic precipitation use sub-time stepping at least for sedimentation. The effect of sub-stepping cloud micro- and macrophysics (cloud fraction and condensation/deposition) on ERFaci+ari was investigated with CAM5.3 [24]. It was found that ERFaci+ari is more sensitive to sub-stepping cloud macrophysics than
Fig. 5 Estimates of ERFaci+ari $\left[\mathrm{W} \mathrm{m}{ }^{-2}\right]$ that include aerosol-cloud interactions in stratiform warm and MPCs (red symbols) and in stratiform and convective clouds (green symbols). In the upper panel best estimates are shown as symbols and if sensitivity experiments were conducted, the minimum and maximum estimates are connected by vertical lines. In the lower panel, the statistics are derived based on the best estimates from each study and where available the SW and LW contributions are shown. " $x$ " denotes the average, the white horizontal line the median, the end of the boxes the $25-75 \%$ range, and the end of the whiskers the minimum-maximum range. A list of the ERFaci+ari estimates with the respective references in the order of occurrence is provided in Table 1
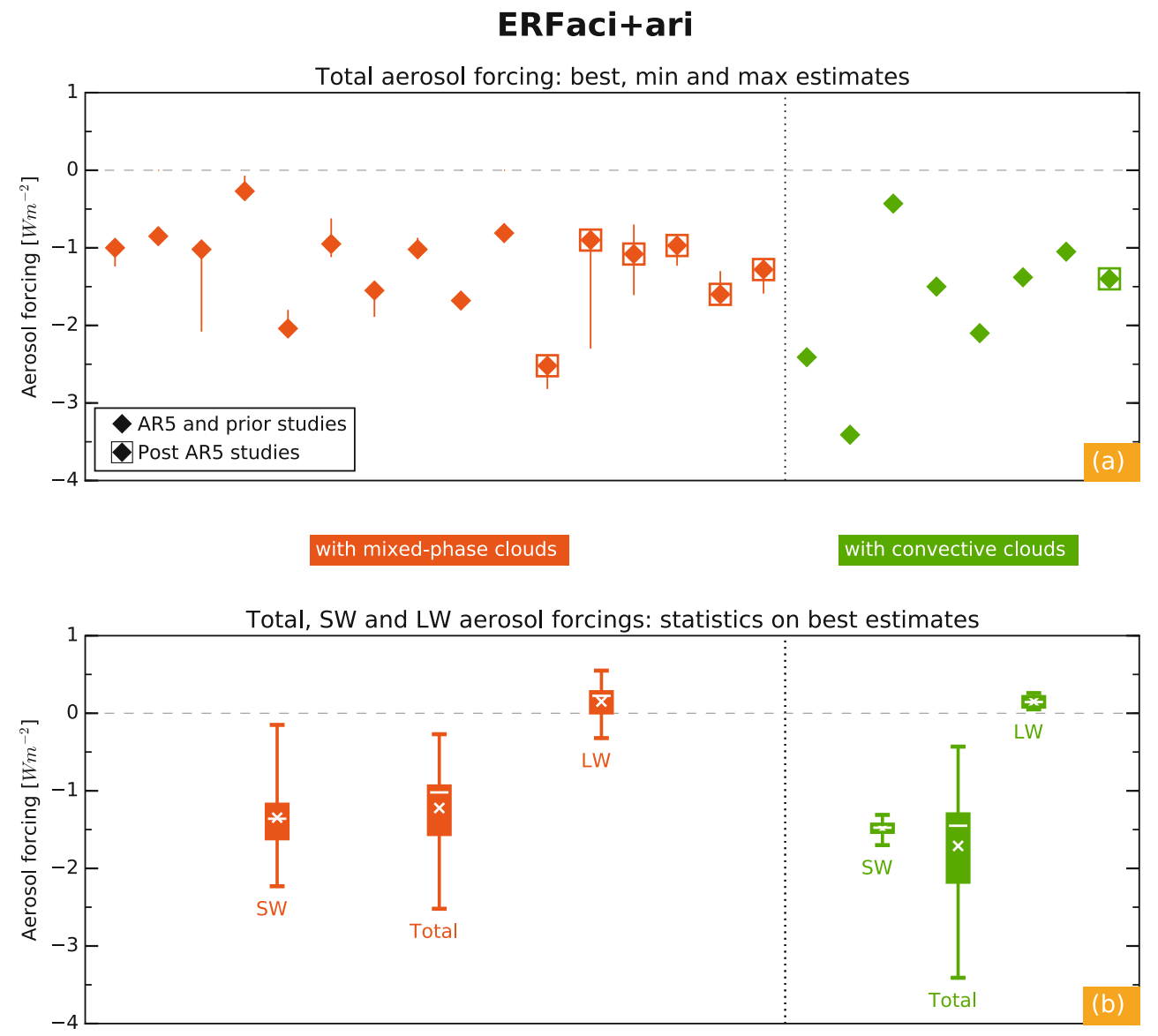
cloud microphysics and that prognostic precipitation lowers ERFaci+ari by 2-33\% as compared to diagnostic precipitation. On the contrary, prognostic precipitation in ECHAM5HAM increases ERFaci+ari by $0.3 \mathrm{~W} \mathrm{~m}^{-2}$, despite a $25 \%$ reduction in the increase in liquid water path in response to anthropogenic aerosols [86]. However, the difference in ERFaci+ari between prognostic and diagnostic precipitation in ECHAM5-HAM is within the interannual variability.

Taking the average ERFaci+ari of the best estimates of those climate model simulations that include aerosol effects on MPCs (red diamonds in Fig. 5) yields $-1.2 \mathrm{~W} \mathrm{~m}^{-2}$, which is significantly more negative than estimated in IPCC AR5 [9]. It agrees with the ERFaci+ari estimate from the GCMs used in the coupled atmosphere-ocean model intercomparison project 5 (CMIP5) [31] of $-1.2 \mathrm{~W} \mathrm{~m}^{-2}$, which as a whole reproduce the observed warming of the twentieth century being dominated by increases in greenhouse gases and aerosol particles [5]. Sensitivity simulations conducted with a given GCM include variations of model's resolution, the parameterization schemes for cloud microphysics (e.g., prognostic vs. diagnostic precipitation) and other processes (coupling to turbulence scheme, impact of natural aerosol emissions or effect of aerosol processing), or the parameterization of a specific process, like the ice nucleation scheme or autoconversion rate. The effect of such sensitivity studies is shown as vertical lines in Fig. 5. For most GCMs, estimates of ERFaci+ari from sensitivity studies vary less than $1 \mathrm{~W} \mathrm{~m}^{-2}$ except for the ones with the ECHAM6-HAM2 GCM [73] where increasing the vertical resolution had the largest effect (Table 1).

An analysis of the CMIP5 models showed that the decrease in the TOA SW radiation is much higher in those two models that consider aerosol effects on MPCs $\left(-1.9 \mathrm{~W} \mathrm{~m}^{-2}\right)$ than in the four models that only consider aerosol effects on warm clouds $\left(-1.2 \mathrm{~W} \mathrm{~m}^{-2}\right)$ [31]. However, the CMIP5 models often use simpler aerosol schemes in order to save CPU time than the atmosphere-only GCMs discussed above. ERFaci+ari from the atmosphere-only GCMs shown in Fig. 5 simulate an average decrease in the TOA SW radiation of only $-1.4 \mathrm{~W} \mathrm{~m}^{-2}$ possible due to
Table 1 List of ERFaci+ari estimates $\left[\mathrm{W} \mathrm{m} \mathrm{m}^{-2}\right]$ shown in Fig. 5 divided into best estimate (best), range, changes in the SW and LW TOA radiation budget, and the category in which the estimate falls (with MPCs or with convective clouds (conv.)), if they were used in AR5 (yes/no) or are post-AR5 (post) estimates and the respective reference

\begin{tabular}{|c|c|c|c|c|c|c|c|}
\hline Cat. & Model & AR5 & Reference & Best & Range & SW & LW \\
\hline MPCs & ECHAM4 & No & Lohmann 2004 [52] & -1.00 & -0.97 to -1.24 & -1.64 & 0.55 \\
\hline MPCs & GATOR-GCMOM & No & Jacobson 2006 [36] & -0.85 & & & \\
\hline MPCs & ECHAM4 & No & Lohmann \& Diehl 2006 [54] & -1.02 & -1.02 to -2.08 & -1.32 & -0.22 \\
\hline MPCs & CAM Oslo & No & Storelvmo et al. 2008 [91] & -0.27 & -0.07 to -0.27 & -0.15 & -0.01 \\
\hline MPCs & ECHAM5-HAM & No & Hoose et al. 2008 [33] & -2.04 & -1.80 to -2.08 & -2.23 & 0.25 \\
\hline MPCs & ECHAM5-HAM & No & Lohmann \& Hoose 2009 [58] & -0.95 & -0.62 to -1.12 & -1.15 & 0.20 \\
\hline MPCs & CAM Oslo & Yes & Hoose et al. 2010 [32] & -1.55 & -1.55 to -1.89 & -1.49 & -0.06 \\
\hline MPCs & ECHAM5-HAM & Yes & Lohmann \& Ferrachat 2010 [56] & -1.02 & -0.87 to -1.12 & -1.07 & 0.05 \\
\hline MPCs & GFDL & Yes & Salzmann et al. 2010 [85] & -1.68 & & -1.99 & 0.31 \\
\hline MPCs & CAM Oslo & Yes & Storelvmo et al. 2010 [92] & -0.81 & & -0.49 & -0.32 \\
\hline MPCs & CAM3+IMPACT & Post & Yun \& Penner 2013 [104] & -2.52 & -2.52 to -2.82 & & \\
\hline MPCs & ECHAM6-HAM2 & Post & Neubauer et al. 2014 [73] & -0.90 & -0.90 to -2.30 & -1.36 & 0.46 \\
\hline MPCs & CAM5-MG1/2 & Post & Gettelman 2015 [23] & -1.08 & -0.70 to -1.61 & -1.36 & 0.25 \\
\hline MPCs & CAM5-MG2-MAM3 & Post & Gettelman et al. 2015 [24] & -0.97 & -0.82 to -1.23 & -1.24 & 0.28 \\
\hline MPCs & ECHAM5-HAM2 & Post & Sant et al. 2015 [86] & -1.60 & -1.30 to -1.60 & -1.80 & 0.10 \\
\hline MPCs & ECHAM5-HAM2 & Post & Tonttila et al. 2015 [95] & -1.28 & -1.28 to -1.59 & -1.55 & 0.27 \\
\hline Conv. & GISS & No & Menon \& Rotstayn 2006 [64] & -2.41 & & & \\
\hline Conv. & CSIRO & No & Menon \& Rotstayn 2006 [64] & -3.41 & & & \\
\hline Conv. & GISS & No & Menon \& DelGenio 2007 [63] & -0.43 & & & \\
\hline Conv. & ECHAM5-HAM & Yes & Lohmann 2008 [53] & -1.50 & & -1.70 & 0.20 \\
\hline Conv. & GISS & No & Unger et al. 2009 [97] & -2.10 & & & \\
\hline Conv. & GISS & Yes & Koch et al. 2009 [45] & -1.38 & & & \\
\hline Conv. & MM5 & Yes & Wang et al. 2011 [98] & -1.05 & & & \\
\hline Conv. & CAM5-CLUBB & Post & Gettelman et al. 2015 [24] & -1.40 & & -1.48 & 0.00 \\
\hline
\end{tabular}


their more sophisticated aerosol schemes. In the two CMIP5 models that consider aerosol effects on MPCs, the longwave ( $\mathrm{LW})$ radiation is reduced by $0.7 \mathrm{~W} \mathrm{~m}^{-2}$ [31], which again is much larger than the averaged change in outgoing LW radiation of $0.15 \mathrm{~W} \mathrm{~m}^{-2}$ from the atmosphere-only GCMs shown in Fig. 5. Note, however, that changes in the LW radiation range from -0.3 to $+0.5 \mathrm{~W} \mathrm{~m}^{-2}$, i.e., the clouds become either more or less transparent to $\mathrm{LW}$ radiation in response to anthropogenic aerosols or experience a decrease or increase in cloud height, respectively.

Until now, the horizontal resolution in GCMs is too coarse to resolve deep convective clouds and hence, they need to be parameterized. Because of that, global estimates of aerosol effects on stratiform and convective clouds are rather uncertain and range between -0.4 and $-3.4 \mathrm{~W} \mathrm{~m}^{-2}$ with an average of $-1.7 \mathrm{~W} \mathrm{~m}^{-2}$ (green diamonds in Fig. 5), which is $-0.5 \mathrm{~W} \mathrm{~m}^{-2}$ more negative than aerosol effects on stratiform warm and MPCs.

Of the eight estimates that include aerosol effects on stratiform and convective clouds, only four provided a breakdown into the changes in SW and LW TOA radiation. These four studies include the three estimates that were used in AR5 plus one new study [24]. Their averaged ERFaci+ari of $-1.3 \mathrm{~W} \mathrm{~m}^{-2}$ is rather comparable to the ERFaci+ari of stratiform warm and MPCs. The averaged SW effect from these four studies is $-1.5 \mathrm{~W} \mathrm{~m}^{-2}$, which again is only slightly more negative than the SW effect of aerosols on stratiform warm and MPCs. The averaged LW effect from these studies of $0.15 \mathrm{~W} \mathrm{~m}^{-2}$ is as large as for aerosol effects on stratiform warm and MPCs.

While in the ECHAM5-HAM GCM evidence for convective invigoration when including aerosol effects on convective clouds was found [53], this did not significantly change ERFaci+ari as compared to a simulation in which aerosol effects on convective clouds were ignored, i.e., the reflection of SW radiation from anvils of polluted clouds as shown in Fig. 3 is negligible.

In a multi-scale modeling framework, where the relevant cloud-scale circulations are resolved, ERFaci+ari is reduced by $40 \%$ from $-1.8 \mathrm{~W} \mathrm{~m}^{-2}$ down to $-1.05 \mathrm{~W} \mathrm{~m}^{-2}$ [98] yielding one of the lowest ERFaci+ari estimates in that category (Fig. 5). In this framework, the liquid water path increases much less in response to anthropogenic aerosols because more buffering mechanisms, such as enhanced evaporation of the smaller polluted cloud droplets, can take place. Because a multi-scale modeling framework is computationally very expensive, other pathways that improve convection in GCMs need to be pursued as well. One promising approach is the spectral convective parameterization representing the statistical effects of a heterogeneous ensemble of cumulus clouds [3] extended with an explicit cloud model based on a one-dimensional steady-state entraining plume [43].

\section{Conclusions}

Mixed-phase clouds remain one of the least studied cloud types because they are not as easy to access as warm clouds and require instrumentation that distinguishes cloud droplets from ice crystals. However, they are persistent at least in the Arctic and in orographic terrain. If they are incorrectly simulated in the present-day climate in global climate models, that can also affect the global mean warming in a $2 \times \mathrm{CO}_{2}$ climate because of the negative cloud phase feedback [94].

Since the publication of the IPCC AR5 report [9], six new global estimates of ERFaci+ari considering aerosol effects on stratiform warm and MPCs are available from atmosphere-only GCMs, ranging between -0.9 and $-2.5 \mathrm{~W} \mathrm{~m}^{-2}$. With that, the average ERFaci+ari on stratiform warm and MPCs is $-1.2 \mathrm{~W} \mathrm{~m}^{-2}$, where the contribution of the changes in LW radiation is rather minor with $+0.15 \mathrm{~W} \mathrm{~m}^{-2}$. This is in line with the recent estimate from re-analyzing the CMIP5 GCMs [31], but is more negative than estimated in IPCC AR5 [9] and as obtained from a simple model [90].

There are only half as many estimates of aerosol effects on stratiform and convective clouds and they are more variable and uncertain. The average ERFaci+ari from those models that provide a breakdown in SW and LW radiation changes of $-1.3 \mathrm{~W} \mathrm{~m}^{-2}$ is comparable to ERFaci+ari considering aerosol effects on stratiform warm and MPCs. Differences between various ERFaci+ari estimates are caused by different parameterization schemes for cloud microphysics and other processes, different aerosol schemes, different base years for pre-industrial emissions (1750 vs. 1850), and different model resolutions. These uncertainties need to be reduced and the estimates of ERFaci+ari from bottom-up estimates need to be reconciled with observations of the temperature record since pre-industrial times to increase our confidence in the anthropogenic aerosol forcing.

Acknowledgments I would like to acknowledge Trude Storelvmo and Zamin Kanji for fruitful discussions, Sylvaine Ferrachat and Fabian Mahrt for help with the figures, and Joel Knain for providing a photograph of a hole punch cloud. The research leading to these results has received partly funding from the European Union's Seventh Framework Programme (FP7/2007-2013) project BACCHUS under grant agreement no. 603445 .

Open Access This article is distributed under the terms of the Creative Commons Attribution 4.0 International License (http:// creativecommons.org/licenses/by/4.0/), which permits unrestricted use, distribution, and reproduction in any medium, provided you give appropriate credit to the original author(s) and the source, provide a link to the Creative Commons license, and indicate if changes were made.

\section{Compliance with Ethical Standards}

Conflict of Interests There is no conflict of interest. 


\section{References}

1. Albrecht B. Aerosols, cloud microphysics, and fractional cloudiness. Science. 1989;245:1227-30.

2. Alterskjær K, Kristjánsson JE, Hoose C. Do anthropogenic aerosols enhance or suppress the surface cloud forcing in the Arctic? J Geophys Res. 2010;115(D22). doi:10.1029/2010JD014015.

3. Arakawa A, Schubert WH. Interaction of a cumulus cloud ensemble with the large-scale envrionment, Part I. J Atmos Sci. 1974;31:674-701.

4. Bergeron T. On the physics of clouds and precipitation. Report, International Union of Geodesy and Geophysics. 1935.

5. Bindoff N, Stott P, AchutaRao K, Allen M, Gillett N, Gutzler D, Hansingo K, Hegerl G, Hu Y, Jain S, Mokhov I, Overland J, Perlwitz J, Sebbari R, Zhang X. Detection and attribution of climate change: from global to regional. In: Stocker T, Qin D, Plattner GK, Tignor M, Allen S, Boschung J, Nauels A, Xia Y, Bex V, and Midgley P, editors. Climate Change 2013: The Physical Science Basis. Contribution of Working Group I to the Fifth Assessment Report of the Intergovernmental Panel on Climate Change, chap. 10. Cambridge: Cambridge University Press; 2013. p. 867-952. doi:10.1017/CBO9781107415324.022.

6. Bodas-Salcedo A, Hill PG, Furtado K, Williams KD, Field PR, Manners JC, Hyder P, Kato S. Large contribution of supercooled liquid clouds to the solar radiation budget of the southern ocean. J Climate. 2016;29(11):4213-28. doi:10.1175/ jcli-d-15-0564.1.

7. Borys RD, Lowenthal DH, Cohn SA, Brown WOJ. Mountaintop and radar measurements of anthropogenic aerosol effects on snow growth and snowfall rate. Geophys Res Lett. 2003;30. doi:10.1029/2002GL016,855.

8. Borys RD, Lowenthal DH, Mitchell DL. The relationships among cloud microphysics, chemistry, and precipitation rate in cold mountain clouds. Atmos Env. 2000;34:2593-602.

9. Boucher O, Randall D, Artaxo P, Bretherton C, Feingold G, Forster P, Kerminen VM, Kondo Y, Liao H, Lohmann U, Rasch P, Satheesh SK, Sherwood S, Stevens B, Zhang X. Clouds and aerosols. In: Stocker T, Qin D, Plattner GK, Tignor M, Allen SK, Boschung J, Nauels A, Xia Y, Bex V, and Midgley PM, editors. Climate Change 2013: The Physical Science Basis. Contribution of Working Group I to the Fifth Assessment Report of the Intergovernmental Panel on Climate Change. Cambridge, United Kingdom and New York, NY, USA: Cambridge University Press; 2013. p. 571-657.

10. Bühl J, Ansmann A, Seifert P, Baars H, Engelmann R. Toward a quantitative characterization of heterogeneous ice formation with lidar/radar: comparison of CALIPSO/CloudSat with ground-based observations. Geophys Res Lett. 2013;40: 4404-08.

11. Bühl J, Seifert P, Myagkov A, Ansmann A. Measuring ice- and liquid- water properties in mixed-phase cloud layers at the leipzig Cloudnet station. Atmos Chem Phys. 2016;2016:10609-10620. doi:10.5194/acp-16-10609-2016.

12. Chen YC, Christensen MW, Stephens GL, Seinfeld JH. Satellite-based estimate of global aerosol-cloud radiative forcing by marine warm clouds. Nature Geosci. 2014;7(9):643-6. doi:10.1038/ngeo2214.

13. Cherian R, Quaas J, Salzmann M, Wild M. Pollution trends over Europe constrain global aerosol forcing as simulated by climate models. Geophys Res Lett. 2014;41(6):2176-81. doi:10.1002/2013g1058715.

14. Christensen MW, Suzuki K, Zambri B, Stephens GL. Ship track observations of a reduced shortwave aerosol indirect effect in mixed-phase clouds. Geophys Res Lett. 2014;41(19):6970-7. doi:10.1002/2014gl061320.

15. Denman K, Brasseur G, Chidthaisong A, Ciais P, Cox P, Dickinson R, Hauglustaine D, Heinze C, Holland E, Jacob D, Lohmann U, Ramachandran S, Silva Dias P, Wofsy S, Zhang X. Couplings between changes in the climate system and biogeochemistry. In: Solomon S, Qin D, Manning M, Chen Z, Marquis M, Averyt KB, Tignor M, and Miller HL, editors. Climate Change 2007: The Physical Science Basis. Contribution of Working Group I to the Fourth Assessment Report of the Intergovernmental Panel on Climate Change. Cambridge, United Kingdom and New York, NY, USA: Cambridge University Press; 2007. p. 499-588.

16. Després V, Huffman J, Burrows S, Hoose C, Safatov A, Buryak G, Fröhlich-Nowoisky J, Elbert W, Andreae M, Pöschl U, Jaenicke R. Primary biological aerosol particles in the atmosphere: a review. Tellus B. 2012:64.

17. Durkee PA, Noone KJ, Ferek RJ, Johnson DW, Taylor JP, Garrett TJ, Hobbs PV, Hudson JG, Bretherton CS, Innis G, Frick GM, Hoppel WA, O’Dowd CD, Russell LM, Gasparovic R, Nielsen KE, Tessmer SA, Öström E, Osborne SR, Flagan RC, Seinfeld JH, Rand H. The impact of ship-produced aerosols on the microstructure and albedo of warm marine stratocumulus clouds: a test of MAST hypothesis 1i and 1ii. J Atmos Sci. 2000;57:2554-69.

18. Fan J, Leung LR, DeMott PJ, Comstock JM, Singh B, Rosenfeld D, Tomlinson JM, White A, Prather KA, Minnis P, Ayers JK, Min Q. Aerosol impacts on California winter clouds and precipitation during Calwater 2011: local pollution versus long-range transported dust. Atmos Chem Phys. 2014;14(1):81101. doi:10.5194/acp-14-81-2014.

19. Fan J, Leung LR, Rosenfeld D, Chen Q, Li Z, Zhang J, Yan H. Microphysical effects determine macrophysical response for aerosol impacts on deep convective clouds. Proc Natl Acad Sci. 2013;110(48):E4581-90. doi:10.1073/pnas.1316830110.

20. Fan J, Leung LR, Rosenfeld D, DeMott PJ. Effects of cloud condensation nuclei and ice nucleating particles on precipitation processes and supercooled liquid in mixed-phase orographic clouds. Atmos Chem Phys Discuss. 2016;2016:1-49. doi:10.5194/acp-2016-772.

21. Findeisen W. Kolloid-meteorologische Vorgänge bei der Niederschlagsbildung. Meteorol Z. 1938;55:121-33.

22. Garrett TJ, Zhao C. Increased Arctic cloud longwave emissivity associated with pollution from mid-latitudes. Nature. 2006;440(7085):787-9.

23. Gettelman A. Putting the clouds back in aerosol-cloud interactions. Atmos Chem Phys. 2015;15(21):12,397-411. doi:10.5194/ acp-15-12397-2015.

24. Gettelman A, Morrison H, Santos S, Bogenschutz P, Caldwell PM. Advanced two-moment bulk microphysics for global models. Part II: global model solutions and aerosolcloud interactions. J Clim. 2015;28(3):1288-307. doi:10.1175/ jcli-d-14-00103.1.

25. Girard E, Sokhandan Asl N. Relative importance of acid coating on ice nuclei in the deposition and contact modes for wintertime Arctic clouds and radiation. Meteorol Atmos Phys. 2014;123(1):81-92. doi:10.1007/s00703-013-0298-9.

26. Glassmeier F, Lohmann U. Constraining precipitation susceptibility of warm, ice- and mixed-phase clouds with microphysical equations. J Atmos Sci. 2016;73:5003-5023. doi:10.1175/JAS-D-16-008.1.

27. Grenier P, Blanchet JP, Munoz-Alpizar R. Study of polar thin ice clouds and aerosols seen by CloudSat and CALIPSO during midwinter 2007. J Geophys Res. 2009;114. doi:10.1029/2008jd010927. 
28. Henneberger J, Fugal JP, Stetzer O, Lohmann U. HOLIMO II: a digital holographic instrument for ground-based in situ observations of microphysical properties of mixed-phase clouds. Atmos Meas Tech. 2013;6:2975-87. doi:10.5194/amt-6-2975-2013.

29. Heymsfield AJ, Kennedy PC, Massie S, Schmitt C, Wang ZE, Haimov S, Rangno A. Aircraft-induced hole punch and canal clouds: inadvertent cloud seeding. Bull Amer Meteorolog Soc. 2010;91(6):753-+. doi:10.1175/2009bams2905.1.

30. Heymsfield AJ, Thompson G, Morrison H, Bansemer A, Rasmussen RM, Minnis P, Wang ZE, Zhang DM. Formation and spread of aircraft-induced holes in clouds. Science. 2011;333(6038):77-81. doi:10.1126/science.1202851.

31. Heyn I, Block K, Mulmenstadt J, Gryspeerdt E, Kuhne P, Salzmann M, Quaas J. Is the IPCC AR5 estimate of the aerosol effective radiative forcing too weak? Geophys Res Lett. in press. 2017.

32. Hoose C, Kristjansson JE, Burrows SM. How important is biological ice nucleation in clouds on a global scale? Environ Res Lett. 2010;5(2):024,009.

33. Hoose C, Lohmann U, Erdin R, Tegen I. Global influence of dust mineralogical composition on heterogeneous ice nucleation in mixed-phase clouds. Environ Res Lett. 2008b;3. doi:10.1088/ 1748-9326/3/2/025,003.

34. Hoose C, Möhler O. Heterogeneous ice nucleation on atmospheric aerosols: a review of results from laboratory experiments. Atmos Chem Phys. 2012;12:9817-54.

35. Jackson RC, McFarquhar GM, Korolev AV, Earle ME, Liu PSK, Lawson RP, Brooks S, Wolde M, Laskin A, Freer M. The dependence of ice microphysics on aerosol concentration in arctic mixed-phase stratus clouds during isdac and m-pace. J Geophys Res. 2012;117(D15). doi:10.1029/2012JD017668.

36. Jacobson MZ. Effects of externally-through-internally-mixed soot inclusions within clouds and precipitation on global climate. J Phys Chem. 2006;110:6860-73.

37. Jiang HL, Xue HW, Teller A, Feingold G, Levin Z. Aerosol effects on the lifetime of shallow cumulus. Geophys Res Lett. 2006;33. doi:10.1029/2006GL026,024.

38. Jirak IL, Cotton WR. Effect of air pollution on precipitation along the front range of the Rocky mountains. J Appl Meteorol Clim. 2006;45(1):236-45. doi:10.1175/JAM2328.1.

39. Joos H, Madonna E, Witlox K, Ferrachat S, Wernli H, Lohmann U. Effect of anthropogenic aerosol emissions on precipitation in warm conveyor belts in the western North Pacific in winter-a model study with ECHAM6-HAM. Atmos Chem Phys Disc. 2016:1-20. doi:10.5194/acp-2016-722.

40. Kanji ZA, Ladino LA, Wex H, Boose Y, Burkert-Kohn M, Cziczo D, Krämer M. Ice Formation and Evolution in Clouds and Precipitation: Measurement and Modeling Challenges: Chapter 1. Overview of Ice Nucleating Particles, Meteorological Monographs, American Meteorological Society, accepted. 2016.

41. Kay JE, Gettelman A. Cloud influence on and response to seasonal Arctic sea ice loss. J Geophys Res. 2009;114:D18,204.

42. Kay JE, Wall C, Yettella V, Medeiros B, Hannay C, Caldwell P, Bitz C. Global climate impacts of fixing the southern ocean shortwave radiation bias in the Community Earth System Model (CESM). J Climate. 2016;29(12):4617-36. doi:10.1175/ jcli-d-15-0358.1.

43. Kipling Z, Stier P, Labbouz L, Wagner T. Dynamic subgrid heterogeneity of convective cloud in a global model: description and evaluation of the Convective Cloud Field Model (CCFM) in ECHAM6-HAM2. Atmos Chem Phys. 2017;2017:327-342. doi:10.5194/acp-17-327-2017.

44. Kirkevåg $\mathrm{A}$, Iversen $\mathrm{T}$, Seland $\mathrm{O}$, Hoose $\mathrm{C}$, Kristjánsson JE, Struthers H, Ekman AML, Ghan S, Griesfeller J, Nilsson ED, Schulz M. Aerosol-climate interactions in the
Norwegian Earth System Model-NorESM1-m. Geosci Model Dev. 2013;6(1):207-44. doi:10.5194/gmd-6-207-2013.

45. Koch D, Menon S, Del Genio A, Ruedy R, Aleinov I, Schmidt GA. Distinguishing aerosol impacts on climate over the past century. J Climate. 2009;22:2659-77.

46. Komurcu M, Storelvmo T, Tan I, Lohmann U, Yun Y, Penner JE, Wang Y, Liu X, Takemura T. Intercomparison of the cloud water phase among global climate models. J Geophys Res. 2014;119:3372-400.

47. Koren I, Kaufman YJ, Rosenfeld D, Remer LA, Rudich Y. Aerosol invigoration and restructuring of Atlantic convective clouds. Geophys Res Lett. 2005;32. doi:10.1029/2005GL023,187.

48. Korolev AV, Isaac GA, Cober SG, Strapp W, Hallett J. Microphysical characterization of mixed-phase clouds. QJR Meteorol Soc. 2003;129:39-65.

49. Kravitz B, Wang HL, Rasch PJ, Morrison H, Solomon AB. Process-model simulations of cloud albedo enhancement by aerosols in the Arctic. Phil Trans R Soc A. 2014;372(2031). doi:10.1098/rsta.2014.0052.

50. Lloyd G, Choularton TW, Bower KN, Gallagher MW, Connolly PJ, Flynn M, Farrington R, Crosier J, Schlenczek O, Fugal J, Henneberger J. The origins of ice crystals measured in mixed-phase clouds at the high-alpine site Jungfraujoch. Atmos Chem Phys. 2015;15(22):12,953-69. doi:10.5194/ acp-15-12953-2015.

51. Lohmann U. A glaciation indirect aerosol effect caused by soot aerosols. Geophys Res Lett. 2002;29. doi:10.1029/2001GL014,357.

52. Lohmann U. Can anthropogenic aerosols decrease the snowfall rate. J Atmos Sci. 2004;61:2457-68.

53. Lohmann U. Global anthropogenic aerosol effects on convective clouds in ECHAM5-HAM. Atmos Chem Phys. 2008;8:2115-31.

54. Lohmann U, Diehl K. Sensitivity studies of the importance of dust ice nuclei for the indirect aerosol effect on stratiform mixedphase clouds. J Atmos Sci. 2006;63:968-82.

55. Lohmann U, Feichter J. Global indirect aerosol effects: a review. Atmos Chem Phys. 2005;5:715-37.

56. Lohmann U, Ferrachat S. Impact of parametric uncertainties on the present-day climate and on the anthropogenic aerosol effect. Atmos Chem Phys. 2010;10:11,373-83. doi:10.5194/acp10-11373-2010.

57. Lohmann U, Henneberger J, Henneberg O, Fugal J, Bühl J, Kanji Z. Persistence of orographic mixed-phase clouds. Geophys Res Lett. 2016;43. doi:10.1002/2016GL071036.

58. Lohmann U, Hoose C. Sensitivity studies of different aerosol indirect effects in mixed-phase clouds. Atmos Chem Phys. 2009;9:8917-34.

59. Lubin D, Vogelmann AM. A climatologically significant aerosol longwave indirect effect in the Arctic. Nature. 2006;439(7075): 453-6.

60. Lynn B, Khain A, Rosenfeld D, Woodley WL. Effects of aerosols on precipitation from orographic clouds. J Geophys Res. 2007;112(D10). doi:10.1029/2006JD007537.

61. Ma XY, Yu FQ. Seasonal and spatial variations of global aerosol optical depth: multi-year modelling with GEOS-CHEM-APM and comparisons with multiple-platform observations. Tellus B. 2015;67. doi:10.3402/tellusb.v67.25115.

62. Marcolli C, Gedamke S, Peter T, Zobrist B. Efficiency of immersion mode ice nucleation on surrogates of mineral dust. Atmos Chem Phys. 2007;7:5081-91.

63. Menon S, Del Genio AD. Evaluating the impacts of carbonaceous aerosols on clouds and climate. In: Schlesinger ME et al., editors. Human induced climate change: an interdisciplinary assessment. Cambridge: Cambridge University Press; 2007. 
64. Menon S, Rotstayn L. The radiative influence of aerosol effects on liquid-phase cumulus and stratiform clouds based on sensitivity studies with two climate models. Climate Dyn. 2006;27: 345-56.

65. Morrison AE, Siems ST, Manton MJ. A three-year climatology of cloud-top phase over the Southern Ocean and North Pacific. J Climate. 2011;24(9):2405-18. doi:10.1175/2010JCLI3842.1.

66. Morrison $\mathrm{H}$. On the robustness of aerosol effects on an idealized supercell storm simulated with a cloud systemresolving model. Atmos Chem Phys. 2012;12(16):7689-705. doi:10.5194/acp-12-7689-2012.

67. Morrison H, de Boer G, Feingold G, Harrington J, Shupe MD, Sulia K. Resilience of persistent Arctic mixed-phase clouds. Nature Geosci. 2012;5(1):11-7.

68. Muelmenstaedt J, Sourdeval O, Delanoe J, Quaas J. Frequency of occurrence of rain from liquid-, mixed-, and ice-phase clouds derived from a-train satellite retrievals. Geophys Res Lett. 2015;42(15):6502-9. doi:10.1002/2015GL064604.

69. Muhlbauer A, Hashino T, Xue L, Teller A, Lohmann U, Rasmussen RM, Geresdi I, Pan Z. Intercomparison of aerosol-cloud-precipitation interactions in stratiform orographic mixed-phase clouds. Atmos Chem Phys. 2010;10(17):8173-96. doi:10.5194/acp-10-8173-2010.

70. Muhlbauer A, Lohmann U. Sensitivity studies of aerosol-cloud interactions in mixed-phase orographic precipitation. J Atmos Sci. 2009;66(9):2517-38. doi:10.1175/2009JAS3001.1.

71. Muraki DJ, Rotunno R, Morrison H. Expansion of a holepunch cloud by a gravity wave front. J Atmos Sci. 2016;73(2):693-707. doi:10.1175/JAS-D-15-0211.1.

72. Murray BJ, O'Sullivan D, Atkinson JD, Webb ME. Ice nucleation by particles immersed in supercooled cloud droplets. Chem Soc Rev. 2012;41:6519-54.

73. Neubauer D, Lohmann U, Hoose C, Frontoso MG. Impact of the representation of marine stratocumulus clouds on the anthropogenic aerosol effect. Atmos Chem Phys. 2014;14:11,9972,022 .

74. Posselt R, Lohmann U. Sensitivity of the total anthropogenic aerosol effect to the treatment of rain in a global climate model. Geophys Res Lett. 2009;36. doi:10.1029/2008GL035,796.

75. Pruppacher HR, Klett JD. Microphysics of clouds and precipitation. Norwell: Kluwer Acad.; 1997.

76. Pummer BG, Bauer H, Bernardi J, Bleicher S, Grothe $\mathrm{H}$. Suspendable macromolecules are responsible for ice nucleation activity of birch and conifer pollen. Atmos Chem Phys. 2012;12:2541-50. doi:10.5194/acp-12-2541-2012.

77. Pummer BG, Budke C, Augustin-Bauditz S, Niedermeier D, Felgitsch L, Kampf CJ, Huber RG, Liedl KR, Loerting T, Moschen T, Schauperl M, Tollinger M, Morris CE, Wex H, Grothe H, Pöschl U, Koop T, Fröhlich-Nowoisky J. Ice nucleation by water-soluble macromolecules. Atmos Chem Phys. 2015;15:4077-91. doi:10.5194/acp-15-4077-2015.

78. Qiu S, Dong X, Xi B, Li JLF. Characterizing arctic mixed-phase cloud structure and its relationship with humidity and temperature inversion using ARM NSA observations. J Geophys Res. 2015;120(15):7737-46. doi:10.1002/2014JD023022.

79. Rosenfeld D, Andreae MO, Asmi A, Chin M, de Leeuw G, Donovan DP, Kahn R, Kinne S, Kivekäs N, Kulmala M, Lau W, Schmidt KS, Suni T, Wagner T, Wild M, Quaas J. Global observations of aerosol-cloud-precipitation-climate interactions. Rev Geophys. 2014;52(4):750-808. doi:10.1002/2013RG000441.

80. Rosenfeld D, Dai J, Yu X, Yao Z, Xu X, Yang X, Du C. Inverse relations between amounts of air pollution and orographic precipitation. Science. 2007;315(5817):1396-8. doi:10.1126/sci ence. 1137949.
81. Rosenfeld D, Lohmann U, Raga GB, O’Dowd CD, Kulmala M, Fuzzi S, Reissell A, Andreae MO. Flood or drought: how do aerosols affect precipitation? Science. 2008;321(5894):1309-13.

82. Rosenfeld D, Woodley WL. Deep convective clouds with sustained supercooled liquid water down to $-37.5{ }^{\circ} \mathrm{C}$. Nature. 2000;405:440-2.

83. Rotstayn LD, Plymin EL, Collier MA, Boucher O, Dufresne JL, Luo JJ, von Salzen K, Jeffrey SJ, Foujols MA, Ming Y, Horowitz LW. Declining aerosols in CMIP5 projections: effects on atmospheric temperature structure and midlatitude jets. J Clim. 2014;27(18):6960-77. doi:10.1175/jcli-d-14-00258.1.

84. Saleeby SM, Cotton WR, Lowenthal D, Messina J. Aerosol impacts on the microphysical growth processes of orographic snowfall. J Appl Meteorol Clim. 2013;52(4):834-52. doi:10. 1175/jamc-d-12-0193.1.

85. Salzmann M, Ming Y, Golaz JC, Ginoux PA, Morrison H, Gettelman A, Krämer M, Donner LJ. Two-moment bulk stratiform cloud microphysics in the GFDL AM3 GCM: description, evaluation, and sensitivity tests. Atmos Chem Phys. 2010;10(16):8037-64. doi:10.5194/acp-10-8037-2010.

86. Sant V, Posselt R, Lohmann U. Prognostic precipitation with three liquid water classes in the ECHAM5HAM GCM. Atmos Chem Phys. 2015;15(15):8717-38. doi:10.5194/acp-15-8717-2015.

87. Schreier M, Mannstein H, Eyring V, Bovensmann H. Global ship track distribution and radiative forcing from 1 year of AATSR data. Geophys Res Lett. 2007;34(17). doi:10.1029/2007 GL030664.

88. Sheffield AM, Saleeby SM, van den Heever SC. Aerosolinduced mechanisms for cumulus congestus growth. J Geophys Res. 2015;120(17):8941-52. doi:10.1002/2015JD023743.

89. Shupe MD, Matrosov SY, Uttal T. Arctic mixed-phase cloud properties derived from surface-based sensors at SHEBA. J Atmos Sci. 2006;63:697-711.

90. Stevens B. Rethinking the lower bound on aerosol radiative forcing. J Clim. 2015;28(12):4794-819. doi:10.1175/jcli-d14-00656.1.

91. Storelvmo T, Kristjánsson JE, Lohmann U. Aerosol influence on mixed-phase clouds in CAM-Oslo. J Atmos Sci. 2008;65: 3214-30.

92. Storelvmo T, Kristjánsson JE, Lohmann U, Iversen T, Kirkevåg A, Seland $\varnothing$. Corrigendum to modeling of the Wegener-BergeronFindeisen process - implications for aerosol indirect effects. Env Res Lett. 2010;5. doi:10.1088/1748-9326/5/1/019,801.

93. Storer RL, van den Heever SC, L'Ecuyer TS. Observations of aerosol-induced convective invigoration in the tropical east Atlantic. J Geophys Res. 2014;119(7):3963-75. doi:10.1002/ 2013JD020272.

94. Tan I, Storelvmo T, Zelinka MD. Observational constraints on mixed-phase clouds imply higher climate sensitivity. Science. 2016;352(6282):224-7. doi:10.1126/science.aad5300.

95. Tonttila J, Järvinen H, Räisänen P. Explicit representation of subgrid variability in cloud microphysics yields weaker aerosol indirect effect in the ECHAM5-HAM2 climate model. Atmos Chem Phys. 2015;15(2):703-14. doi:10.5194/acp-15-703-2015.

96. Twomey SA. Pollution and the planetary albedo. Atmos Env. 1974;8(12):1251-6. doi:10.1016/0004-6981(74)90004-3.

97. Unger N, Menon S, Shindell DT, Koch DM. Impacts of aerosol indirect effect on past and future changes in tropospheric composition. Atmos Chem Phys Discuss. 2009;9:4691-725.

98. Wang M, Ghan S, Ovchinnikov M, Liu X, Easter R, Kassianov E, Qian Y, Morrison H. Aerosol indirect effects in a multiscale aerosol-climate model PNNL-MMF. Atmos Chem Phys. 2011;11:5431-55. 
99. Wang Y, Wang M, Zhang R, Ghan SJ, Lin Y, Hu J, Pan B, Levy M, Jiang JH, Molina MJ. Assessing the effects of anthropogenic aerosols on Pacific storm track using a multiscale global climate model. Proc Natl Acad Sci. 2014;111(19):6894-9. doi:10.1073/pnas.1403364111.

100. Wegener A. Thermodynamik der Atmosphäre. Germany: Barth,Leipzig; 1911.

101. White B, Gryspeerdt E, Stier P, Morrison H, Thompson G. Can models robustly represent aerosol-convection interactions if their cloud microphysics is uncertain? Atmos Chem Phys Discuss. 2016;2016:1-35. doi:10.5194/acp-2016-760.

102. Wilson TW, Ladino LA, Alpert PA, Breckels MN, Brooks IM, Browse J, Burrows SM, Carslaw KS, Huffman JA, Judd C, Kilthau WP, Mason RH, McFiggans G, Miller LA, Najera JJ, Polishchuk E, Rae S, Schiller CL, Si M, Temprado JV, Whale TF, Wong JPS, Wurl1 O, Yakobi-Hancock JD, Abbatt JPD, Aller JY, Bertram AK, Knopf DA, Murray BJ. A marine biogenic source of atmospheric ice-nucleating particles. Nature. 2015;525(7568):234-8. doi:10.1038/nature14986.
103. Young G, Jones HM, Darbyshire E, Baustian KJ, McQuaid JB, Bower KN, Connolly PJ, Gallagher MW, Choularton TW. Size-segregated compositional analysis of aerosol particles collected in the European Arctic during the ACCACIA campaign. Atmos Chem Phys. 2016;16(6):4063-79. doi:10.5194/ acp-16-4063-2016.

104. Yun Y, Penner JE. An evaluation of the potential radiative forcing and climatic impact of marine organic aerosols as heterogeneous ice nuclei. Geophys Res Lett. 2013;40(15):4121-6. doi:10.1002/grl.50794.

105. Zhou R, Deng Y. A model analysis of the interactions between East Asian anthropogenic aerosols and North Pacific atmospheric transients in boreal winter. J Geophys Res. 2013;118:306-16. doi:10.1029/2012jd018649.

106. Zubler EM, Lohmann U, Lüthi D, Schär C, Muhlbauer A. Statistical analysis of aerosol effects on simulated mixedphase clouds and precipitation in the Alps. J Atmos Sci. 2011;68(7):1474-92. doi:10.1175/2011jas3632.1. 